\title{
Law Reformation of Economic and Bankrupting Policy, under the Framework of European Integration
}

\author{
Prof. Assoc. Dr Alba Dumi \\ Dean of Graduated School, Ismail Qemali" VIore University, Albania \\ Email: alba.besi12@gmail.com \\ PhD. Edit Ura \\ Accounting and Minor Finance, NY College \\ Hunter College, 695 Park Avenue 10065 NY, USA \\ Email: uraedit@gmail.com

\section{Ma Florina Mehmeti}

SEEU University, Macedonia, Law Faculty, Administrative branch Email: florinamemeti@seeu.edu.mk

\section{Doi: $10.5901 / m j s s .2013 . v 4 n 4 p 163$}

\section{Abstract}

\begin{abstract}
Bankruptcy represents inability of legal or phisic person to pay their dues at the time specified. The collapse can lead to bankruptcy procedure, which will be taken legal action where the assets may be liquidated to pay outstanding debts. Today business and finance indisputably are global. The financial and capital markets are more globally integrated and move much more rapidly in response to events. As a result, many financial institutions and activities that once were local are now international. The changes in the international financial system have been driven by deregulation, by improvements in communications, by technological changes that have increased the speed and volume of transactions enormously, and by widespread innovation in markets, organizational structures, services and instruments. Often overlooked in the debate over globalization, however, is that smaller businesses and financial institutions participate in global trade and finance on an unprecedented scale.In this paper research we are trying to analyze the benkrupting in Albania and Macedonia benking system.
\end{abstract}

Key words: Bankruptcy, finance institutions,technology transactions, innovation in technological changes,

\section{Introduction}

The interactions of businesses at all levels of the markets for goods, services, and financial assets affect the prices for goods, cost of capital, availability of credit, value of businesses, and economic efficiency of all countries. ${ }^{1}$

While business and finance are global regulatory systems, laws are not viewed as such. There are few international rules and norms to govern the relationship between financial institutions, payment systems and markets. This is particularly reflected in banking and financial services sector. National laws define the links between domestic banks, international banks and other financial institutions. A crucial process that is governed exclusively by national law is the choice of procedures of failed banks.

\subsection{Depository institutions and banking law}

This includes those financial firms whose main characteristic is accepting deposits and lending. These companies create financial instruments on both sides of the balance sheet. On assets they may buy existing financial instruments, mainly

\footnotetext{
1 Deposit Insurance and Bank Insolvency in a Changing World: Synergies and Challenges Michael H. Krimminger International Monetary Fund Conference 
government securities, but in some places you can buy shares of manufacturing firms to a limited extent provided by law. These institutions are active in derivative markets and in markets SWA (direct exchange of income of instruments, etc.). On the liabilities these institutions accept deposits, savings deposits, time deposits, etc. Depository institutions appear in different forms.

Tab 1 The depository institutions and banking law improvements, Source : Krimminger M 2011

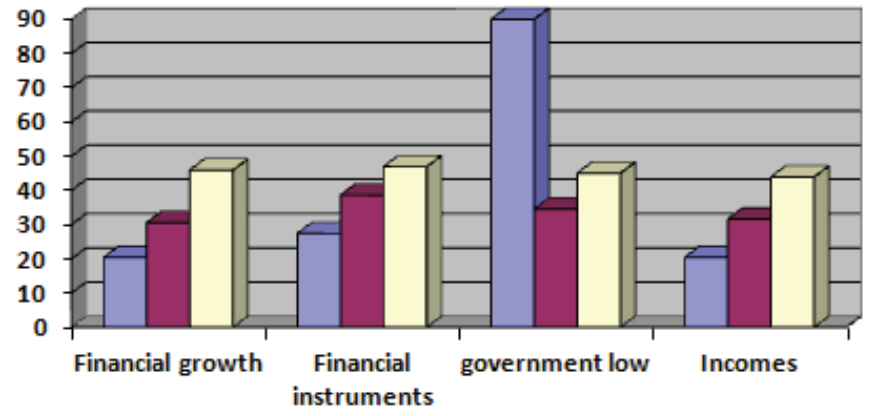

$\square$ Banking reforms
$\square$ Commercial banks
$\square$ SWA and SWS

Commercial Banks: represent the most popular depository institutions that have as their main feature coequal deposits and merchant lending and the purchase of government securities. Commercial banks also accept saving deposits and give loan to consumers in the form of mortgage.

Credit Banks: credit banks historically have been created by the utopian socialist Robert Owen, who with his humanist desire to help people set up credit cooperatives operated under this principle "each deposit as much as he can and get as much as he needs".

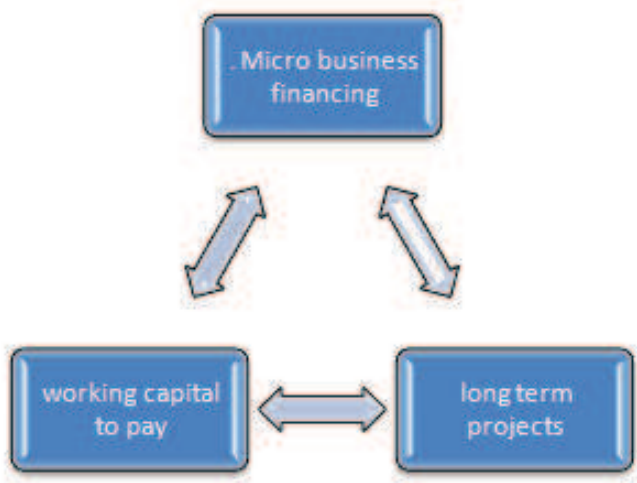

Tab 1.The cycle economic developments, Source WEF-Policy 2008

\section{Literature Review and Hypotheses}

\subsection{International trade and volume of the trade}

One the major trading partners of the firm home country and those of the nations where it has affiliates that export can provide valuable insights to management. According to the definition, of Martin Wolfe, Global Business analyst (Financial Times, October 1, 1997, pp.12) "Creating overseas production cities merely in order to meet local consumption looks an increasingly fragile basis for foreign investment.A much better one is the ability to make the best use of companiescompetitive advantage by locating production wherever it is most efficient. Why focus on major trading partners? 1).Business climate in importing nations is relatively favorable 2).Export and Import regulations are not insurmountable 
3).There should be no strong cultural objections to buying that nations- goods 4).Satisfactory transportation facilities have already been established.

\subsection{Bankrupting and management of banks}

Insolvencies of banks and similar financial firms create additional problems. The Bank relies on a known empiric principle, according to which the completion of average needs for attraction deposits accomplished by keeping only a fraction of deposits as reserves, while the rest can be lent. Problem is that the amount of the withdrawal of deposits may vary from the average, and in certain conditions, the volatility can be quite high. But, if the bank bears no withdrawal requirements, it can be turned in banking panic, leading to the bankruptcy of the bank. Therefore, banks are highly sensitive to the level of confidence that depositors have against them, and for this purpose the bank uses several key techniques of liquidity management.

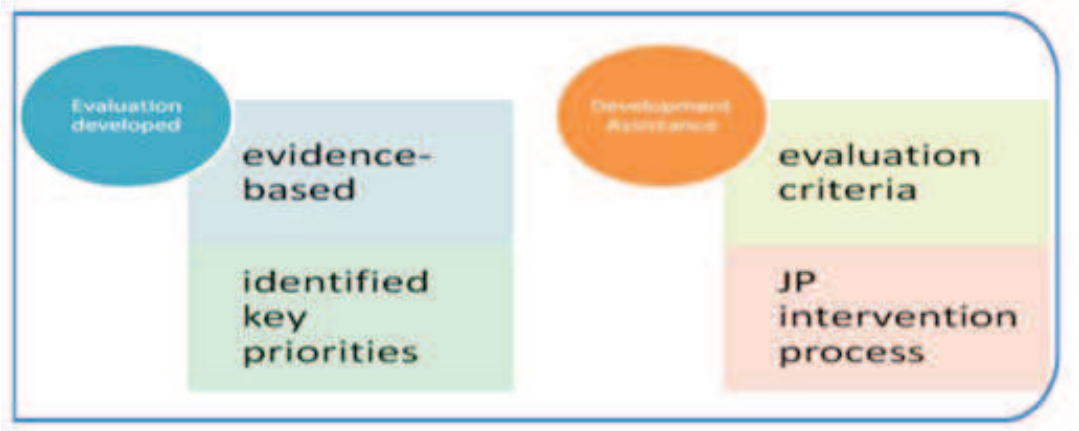

Tab 2 Remittances augment the recipients' incomes and increase their country's foreign exchange reserves.

Due to the short-term liquidity of most banks' primary liabilities, banks are uniquely dependent on public trust for funding. The largest banks have substituted the reliance on deposits for funding with market instruments. However, this simply has substituted reliance on depositor trust for reliance on market trust and, indeed, may have increased the risk of a liquidity collapse through a "market run." In short, a weakening large bank relying on the market for funding could find itself effectively excluded from the market by the increased costs of collateral and spreads.

\subsubsection{The government of financing projects}

Economic integration between the two Albanian nations will certainly grow, and it is true that the route through Albania, unlike those through Serbia and Macedonia, faces no great geopolitical risks. Yet improvements to the existing two-lane road could have achieved the same goal at a fraction of the cost. The planned four-lane highway can wait until there is enough growth in trade and traffic to justify it. This project lacks an economic rationale and, unsurprisingly, private capital has stayed away from it.

The government undertook the project without a plan, feasibility study, or financing. The highway's name reveals the real reason behind the project: it is a "Patriotic Highway". This is an unaffordable act of patriotism, though: an agreement forged between Kosovo and the IMF in June 2010 - which Kosovo irresponsibly broke a few months later was effectively an attempt to save Kosovo's budget from the weight of this huge expenditure. The attempt failed, and the fate of Kosovo's budget remains uncertain.

The key intuition behind our central result is that, because the total value of the available tax expenditures (once tax expenditures for capital income are excluded) going to high-income taxpayers is smaller than the tax cuts that would accrue to high-income taxpayers, high-income taxpayers must necessarily face a lower net tax burden. As a result, maintaining revenue neutrality mathematically necessitates a shift in the tax burden of at least $\$ 86$ billion away from highincome taxpayers onto lower- and middle-income taxpayers. This is true even under the assumption that the maximum amount of revenue possible is obtained from cutting tax expenditures for high-income households.

In order to build this highway, the government risks a fiscal crisis and has had to cut other much-needed capital expenditures that could have been more productive. Kosovo's education system needs attention, for example, and 
schools operate on three or even four shifts a day. The highway is also absorbing money that should have been channeled to the private sector instead to stimulate sustainable growth. Money could have been well spent elsewhere, as Kosovo's fiscal crisis is grave: unemployment is $45 \%$ - $75 \%$ among the youth - and $45 \%$ of the population live in poverty, $13 \%$ in extreme poverty (meaning, without the minimum income needed to buy enough food to remain healthy).

\subsubsection{Effectively in "market run" and implication of banking system}

As commentators have noted, the resulting "market run" as counterparties liquidate contracts and impose additional costs on the weakening bank could increase the speed of its collapse. It is a truism that the less time available for planning a resolution of a failing bank, the greater the potential losses and disruption. In such cases, the loss of confidence in one bank can have dire implications for confidence in the overall banking system.

Another truism is that deposit insurance is designed, in part, to maintain public confidence in the banking system during times of institution-specific or broader systemic stress by reassuring depositors that their funds, or at least the insured maximum, will be protected even if their bank is closed. Deposit insurance thus exchanges the preexisting dynamic of depositor and market discipline, in part, for a regulatory buffer along with regulatory oversight.

\subsubsection{Short-term liability and the deposit based banking development}

While insured banks remain reliant on public trust, that trust is supported, and perhaps supplanted to a degree, by public trust in the efficacy and reliability of the governmental promise of payment in an in solvency. On the other hand, if the deposit insurer does not or cannot, fulfill the promise of payment within an acceptable time the short-term liability problem inherent in deposit-based banking will create recurring crises as depositor confidence ebbs and flows. Once again, the reduction of uncertainty is as important to deposit-based institutions as it is to market-based institutions. (Maechler and McDill. 2003)

Graph 1. Annual rate LIBOR in usd.

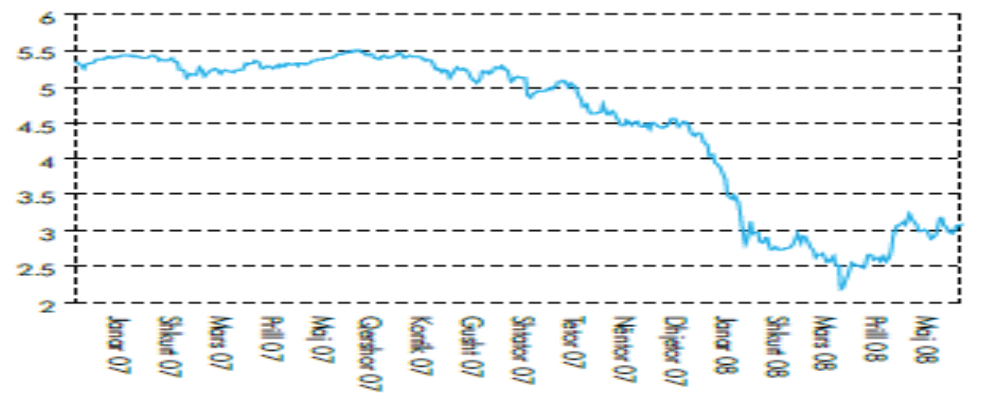

\subsubsection{Deposit insurance and market discipline}

Whether dealing with a smaller, deposit-based bank or a larger, more market-based bank, the goals of an insolvency process must focus on promptly returning insured funds to depositors, maintaining critical bank functions, and ensuring public confidence Deposit Insurance \& Bank Insolvency in the equity of the resolution process. Speed is a fundamental element in an effective bank insolvency process. Returning cash to insured depositors quickly is as important as assurance of payment. Speed in taking over and continuing failing bank functions - whether payments processing, credit, or capital markets settling - limits the loss of value in the bank's assets, halts a potentially dangerous spread of settlement failures, and reduces the contagious loss of confidence in other banks. However, speed must be matched by equity.

Predictability and reliability of the process are essential if public and business confidence is to be maintained in the banking system. But the Kosovo government had to show the contract to the World Bank and the IMF with which it was negotiating its program. And, a mere two months after having announced a price of 659 million Euros, the government 
accepted a World Bank estimate placing the total cost of the highway at at least one billion Euros - which, incidentally, brings the per-kilometer price slightly above Strabag's bid.

\subsection{Components of Effective Bank Insolvency Laws}

As noted by many international organizations and commentators, there are some common components of effective bank insolvency laws. First, the overall legal infrastructure of the country must support the insolvency system. An important component of this legal infrastructure is effective and predictable commercial legal rules. A well-developed commercial law is a crucial prerequisite to functioning markets for goods, services and financial assets as well as a reliable business climate. Second, the laws must have clear criteria for initiating insolvency proceedings.(Michael K 2009)

The highway project has also been poorly implemented. The procurement process was seriously flawed as bidders submitted offers which could not be compared according to objective criteria. The runner-up, Austria's Strabag, offered a 1.3 billion Euro fixed price for the whole highway (approximately 140 kilometers, running from the border with Serbia to the border with Albania), whereas the winner - a consortium formed by US's Bechtel and a smaller Turkish company, Enka - offered a variable price for the segment running from Pristina to the Albanian border (approximately 110 kilometers). Furthermore, the construction contract was negotiated after the winning bidder had been chosen when the negotiating power of the government was lowest. In fact, during the negotiations, the estimated price of the highway rose by more than 60 percent, from about 400 to 659 million Euros $\underline{3}$. The contract proposed by Bechtel-Enka contains very punitive clauses that were not contemplated by the tender rules.

This is particularly crucial in banking insolvencies where otherwise insolvent banks may be able to continue indefinitely by raising funds from depositors and act as a drag or diversion of economic capital. Clear, mandatory criteria permit prompt and decisive action before the bank's equity is exhausted. The criteria should be mandatory to require supervisory action as capital or other indicia of institutional soundness erode. In effect, mandatory action requirements create the supervisory discipline that augments market discipline. (Michael K, 2009) Finally, this process should be designed to reimburse depositors up to the insured maximum as soon as possible, while minimizing the cost to the deposit insurance fund. While depositor confidence in the guarantee is based on the certainty of repayment, it is equally based on the speed of repayment (Mathew 2011)

\section{Methodology}

\subsection{Research Goal and Macedonia case study.}

In this survey we aim to identify the mediating effect of strategic developing of economical system in Macedonia.

Nowadays people enjoy a greater sphere of rights reffered to the right enjoyed by the individuals before ' $90-s$,eventhough some rights recognized by law of that time could not find application in everyday life. Another remarkable difference is that today people enjoy several colateral rights that were not recognized by the law of that time. The factors that have brought the evolution of the law-right \& justice are different regarding to economic ones,political as well as demographic etc.Another question that evidently comes out is: "Have these changes been effective for todays' society? Garrett, N., Abbott, M. Cheung, V and De Souza, R. (2007)

\subsubsection{The USA experience and development economy indicators}

We make the following assumptions:

Any reductions in revenue due to the lower corporate rate would be offset by reducing corporate tax preferences. As a result, we examine only changes to the individual income tax, alternative minimum tax, payroll tax, and estate tax. We ignore the effect of the proposal to reduce the corporate rate to 25 percent. If we assume, as in their model, that 21.3 percent of capital income taxes and 13.5 percent of labor income taxes are offset by higher growth after five years this would imply a revenue offset of 14.7 percent. (Assuming the tax cuts are 85 percent labor and 15 percent capital, which is roughly the share of labor and capital income reported on individual tax returns) The price is the highest in the region and seems rather high also for EU standards - it could also rise much higher through design revisions, extra costs or penalties, and an acknowledgment that «the highway contract may not adequately protect the budget from cost overruns, while construction delays would trigger non-negligible penalties and cost increases 


\subsection{Bankrupting in banking system in republic of Macedonia}

In the Macedonian banking system "burned over $\$ 50$ million" - nobody asks where did the money go!!! IMF in his own regularly report from May - June 2004, among other things said: "In Macedonian banking sector there are banks that are badly managed, with in-transparent and suspicious stock structure, banks that shareholders use for their own business financing". At the same time the IMF experts for these banks, called these banks " pockets banks "! The worst in these banks is that there disappeared 50 - \$70 million state money and no one responded for this. In all this "story " more expressed is the case with three banks

a) Export-Import Bank Skopje: Ex Governor of the National Bank of Macedonia, prof. Lube Tërpeski, speaking in front of the country's parliamentarians about the events in the bank will declare: "Some dominant shareholder in several banks understand the bank as an own supermarket- when you need money to get loan from them". Lube Trpeski government is on investigation procedure for government guarantee and payment of $\$ 24$ million from the state budget to cover losses of National Bank of Macedonia caused by its guarantee given to ExportImport Bank from the foreign currency reserves of the country! He prosecuted for abuse of his work because was aware of the difficult situation of the bank and again has given guarantee for two loans \$ 24 million. In addition Ministry of Internal Affairs- the criminal sector made criminal charges for bank owner - controversial person Metodija Smilenski, former general director of the electro economy - Lambe Arnaudov and two bank directors (Jovica Krajcev and Jasmina Krajceska).

b) Bank bankruptcy was the result of: In May 2001, the National Bank of Macedonia gives \$ 12 million bank guarantee from the German bank LHB with cover only 30 PP formula and in 2003 (when the bank had fallen in no liquidity) and 5 bills. This loan is intended entirely for $4-5$ other firms that have had direct commercial links with its owner - Smileski and in the end of 2001, after some financial flows the money reach in a bank in Nicosia

c) In the middle of year 2002, as the bank has entered the zone of insolvency, its owner, helped out from others (mentioned in the investigator), again make a similar construction, this time with Bank Austria therefore again NBM gives the guarantee (through its deposit) for alleged loans intended for Power Company in the amount of $\$ 10$ million, which happens. In 2004, Austria's Bank collects its requirements of NBM in the amount of $\$ 9.16$ million, as the Export-Import Bank has been blocked.

d) Rado Bank loss was about $2.5-4.2$ million as loans, loan guarantees or financial support to Export-Import Bank. Also the Bank for support of development (bank with dominant government capital) melt 1.6 million in Rado Bank and Macedonian Railways allowed to Rado Bank to sup 0.4 million Euros knowing the position of this bank. The son of the Governor of NBM - Orce Trpeski, during all this time worked on Rado Bank!!!

\section{Conclusion and Recommendation}

Recent analyzes have identified some generally accepted principles for effective solutions to the problems of financial institutions. These principles are based on the goal of maximizing the value of the property for the benefit of all creditors in a fair, transparent, predictable process and minimizing the cost of the solution. In addition, we also assess whether these results hold if we assume that revenue reductions are partially offset by higher economic growth. Although reasonable models would show that these tax changes would have little effect on growth, we show that even with implausibly large growth effects, revenue neutrality would still require large reductions in tax expenditures and would likely result in a net tax increase for lower- and middle-income households and tax cuts for high-income households.

It would be possible to reduce the regressive of such plans or even to maintain progressivity in such plans with reductions in the tax rate cuts for high-income taxpayers and/or significant reductions in the tax preferences for saving and investment, including the preferential rates on capital gains and dividends

Achieving of these goals requires an effective and efficient legal and institutional infrastructure. The ability of each nation to ensure greater safety, efficiency, and equity in a bankruptcy processes depends on the environment conditional to the laws of his culture, markets, the availability of trained professionals (bank employees, accountants, lawyers), governmental competences, and economic level. In the context of revenue-neutral tax reform, any positive growth effects are likely to be small. While the lower tax rates under the reform would strengthen incentives for employment and savings, the base broadness would increase the portion of income that is subject to tax and have incentive effects in the opposite direction. For example, a functioning bankruptcy system must have well designed bankruptcy laws, but also it is necessary to have laws which provide the basis for undertaking business activities, to ensure the rights of the creditor and the debtor. 


\section{References}

Andrea Maechler \& Kathleen McDill, "Dynamic Depositor Discipline in U.S. Banks", FDIC Working Paper 2003-7 (Nov. 2003);

Global Bank Insolvency Initiative, "Legal, Institutional, and Regulatory Framework to Deal with Insolvent Banks"; Financial Stability Forum, "Guidance for Developing Effective Deposit Insurance Systems" at 8-11 (Sept. 2001)

Adams, R. 2004. "Remittances and Poverty" Policy Research-Working ,Paper 3418, World Bank, Washington DC.

Deposit Insurance and Bank Insolvency in a Changing World: Synergies and Challenges Michael H. Krimminger International Monetary Fund Conference

Chami, R and S. Jahjah. 2003. "Are Immigrant Remittance Flows a Source of Capital for Development?" Working Paper No. 03/189,

The International Bank for Reconstruction and Development / the World Bank16 Remittances: An Overview

Gammeltoft, Peter. 2002. "Remittances and Other Financial Flows to Developing Countries." Working Paper 02.11, Centre for Development Research, Copenhagen, Denmark. http://www.cdr.dk/working_papers/wp-02-11.pdf.

Ketkar, S. and D. Ratha. 2004. "Recent Advances in Future-Flow Securitization". Paper presented at Annual Finance \& Accounting International Conference - Managing Securitization for Lebanon and the MENA Region,

December 3-4, Lebanese American University, School of Business, Beirut, Lebanon.Ratha, Dilip. 2003. "Worker's Remittances: An Important and Stable Source of

External Development Finance." In Global Development Finance: Striving for Stability in Development Finance (157-75). Washington, DC: World Bank.

U.S.Department of State. 2004. "G8 Action Plan: Applying the Power of Entrepreneurship to the Eradication of Poverty." The White House Office of the Press Secretary, Sea Island, Georgia, June 9

Prof.Dr. Abdylmenaf Bexheti, makroekonomi - Ligjerata te autorizuara pp 23,56,79

Prof.Dr. Sulo Hadwri, Paraja, bankat dhe tregjet financiare, fq. 83, 84

Michael H. Krimminger, Deposit Insurance and Bank Insolvency in a Changing World: Synergies and Challenges, International Monetary Fund Conference pp 12.2009 
